\title{
Film Le Dēpart by Jerzy Skolimowski: Important Unknown Piece of Art
}

\begin{abstract}
Iwona Grodź
Adam Mickiewicz University, Poznań, Poland

The aim of this essay is firstly to indicate a little-known film Le Dēpart made by the famous Polish director Jerzy Skolimowski in 1967 year as an example of the Polish New Wave. Although it was made in Belgium and it stars Jean-Pierre Léaud as a car-obsessed young man trying to get possession of a Porsche for a race. The film won the Golden Bear at the 17th Berlin International Film Festival and was also selected as the Belgian entry for the Best Foreign Language Film at the 40th Academy Awards, but was not accepted as a nominee. Secondly, I analyze the reasons of misunderstanding the idea of the director in the film when it was shown in the the public. Thirdly, "entering" this movie in context of art: poetry, painting etc. Then to answer the question (hypothesis): "Is the Polish Film New Wave a phenomenon that did not exist?" The methodology used for the paper is analysis and interpretation of the film itself; analysis of its reception in the 60 s and now: poetics of receipt, cognitivism, comparative research.
\end{abstract}

Keywords: New Wave in cinema, Jerzy Skolimowski, Polish film, Le Dēpart

There are two types of visual memory: one is about reconstructing a picture in the laboratory of the mind, with the eyes open $[\ldots]$; the other type makes it possible to immediately have an objective, absolutely optical replica of the beloved face, apparition in natural colors, on the dark lining of closed lids.

- Vladimir Nabokov

Lolita (n.d.)

\section{Introduction}

It is said that there are films whose real taste we learn to appreciate after some time. We can even say that they mature like good red wine ... and only after some time do they uncover before us new flavors and aromas. Many times we watch a completely unknown film, which surprises us with its maturity and originality. There are also pictures which we have seen several times with the "eyes open" and now we keep them in the "laboratory of our mind", but only after some years are we able to invoke their true image "in natural colors (...) on the dark lining of closed lids (...)”. There are many such movies. Sometimes it is difficult, sometimes it is easy to talk about them.

Iwona Grodź, Doctor, Lecturer, Faculty of Polish and Classical Philology (Institute of Polish Philology, Department of Film, Television and New Media), Adam Mickiewicz University. 
Jerzy Skolimowski is one of underestimated, or rather forgotten artists. ${ }^{1}$ Here I primarily mean all his films that were created after his successful debut in Poland, that is the first small productions the director made abroad, e.g. Start (Le Dēpart) (Belgium, 1967) and Na samym dnie (Deep End) (Federal Republic of Germany, USA, 1970). Both are interesting, however, I think that the former one is worth focusing on for two reasons. Le Dēpart is the first foreign project of the director. In Poland it is hardly known, it has not been screened and it does not exist in the consciousness of viewers, even the lovers of films by the author of Rysopis (Identification Marks: None). Second of all, it is a film which was recognized abroad, as it was awarded the Golden Bear in Berlin. At that time it also received many good reviews. "A novelist Marguerite Duras said on the radio that it was the only film worthwhile that she had seen in Cannes, whereas film critic Richard Roud wrote in the British The Guardian that the screening of Skolimowski's film proved to be one of those events for which it is worth going to the festival at all".2 In Poland and for the Polish viewer the film did not exist at all.

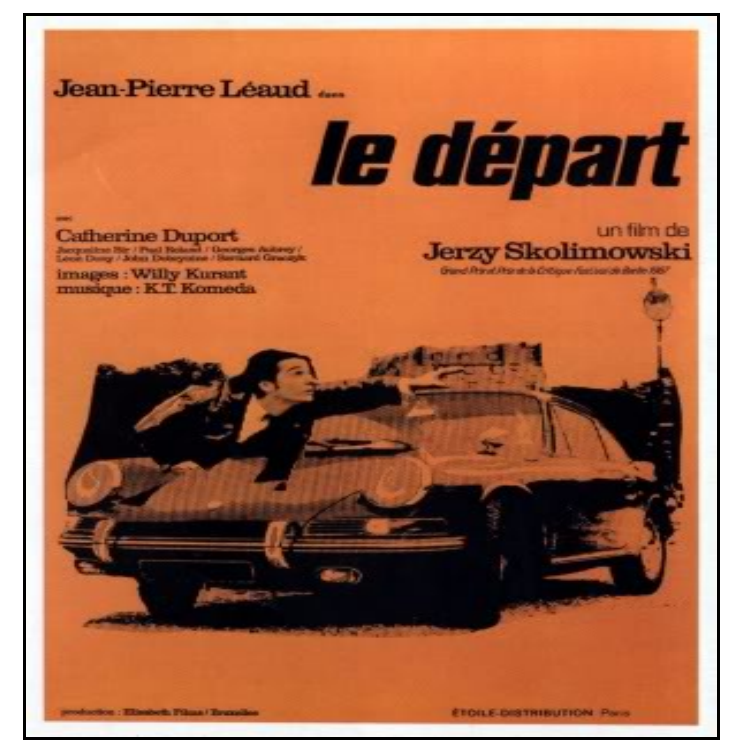

Figure 1. Fotos for the film Le départ by Jerzy Skolimowski (1967).

Moreover, it is said that Le Dēpart (see Figure 1) was a significant film also because it "cured" Skolimowski of his dreams, it was a stepping stone to adulthood. ${ }^{3}$ It is a film made in Belgium. At first a completely different project was to be carried out (a film called Śmietnik (Dumpster)). Unfortunately, in the end the director presented the producers with a completely new screenplay. This is how Skolimowski told the story which became the backbone of the film:

\footnotetext{
1 See about Jerzy http://culture.pl/en/artist/jerzy-skolimowski; http://sensesofcinema.com/2003/great-directors/skolimowski/; http://sensesofcinema.com/2014/2014-melbourne-international-film-festival-dossier/le-depart/.

2 See B. S. Filmy, o których się mówi (Films that are talked about): "Le Dēpart", "Film" 1967, no. 23, p. 3. More: A. Jackiewicz, Skolimowski belgijski (Belgian Skolimowski), "Film" 1967, no. 50, p. 14; M. Oleksiwicz, Podarunek dla aktora (A gift for an actor), "Film" 1969, no. 10, p. 5. Reviews of his films can also be read in: J. Fuksiewicz, "Kultura" 1969, no. 6, p. 12; S. Grzelecki, "Życie Warszawy" 1969, no. 19, p. 4; A. Jackiewicz, "Życie Literackie” 1969, no. 10, p. 7; Jaszcz (Jan Alfred Szczepański), “Życie Warszawy” 1969, no. 2, p. 8; Z. Kałużyński, "Polityka” 1969, no. 8, p. 1; R. Marszałek, "Współczesność" 1968, no. 1, p. 12.

${ }^{3}$ See Filmy, o których się mówiło w 1967 roku (Films that were talked about in 1967), “Film” 1967, no. 51-52, pp. 14-15.
} 
(...) a glider lands at a dumpster in Holland or Belgium. A man from the East broke the flight duration record, escaped the control and landed. At the dumpster there is also an excavator with a worker who operates it, and a girl - three persons. The one from the glider does not know any language; I identified myself with him at the time. They try to speak by signs, a few of words in English, in French, and even in Latin. Some common language is being created between the girl and the glider pilot, but the third one is interrupting them. ${ }^{4}$

This account shows how the initial idea has been transformed. In the end Le Départ was made in only 20 days. It cost 4,000 dollars. For the money the director bought a Ford Mustang, a fact which was not insignificant for those who have seen the film.

\section{Explication-Analysis and Interpretation of the Film}

Le Dēpart is a story of a young boy Marc (played by Jean-Pierre Léaud, an actor know to the viewers from another film, Les 400 coups), who is fascinated by fast cars and intends to take part in a race. Unfortunately, he does not have a car. The storyline is therefore quite simple. It is about getting the money to rent the dream Porsche from a car showroom for the race. It is not worth summarizing it; instead viewers should be encouraged to see the story, which is told in a light and playful manner, which was completely different from Skolimowski's earlier films which were clearly symbolic with meandering narration: Rysopis (Identification Marks: None) (1964), Walkower (Walkower) (1965), Bariera (Barrier) (1966), Ręce do góry (Hands Up!) (1967). At the time, the critics pointed to commonalities of this film with New Wave projects, e.g. Jean-Luc Godard, but the director himself claimed that this parallelism is purely accidental, as at that time he did not know those films at all.

It is, however, worth mentioning the last sequence, starting from the scene of renting a room in the town where the car race is to start. Why is it the end of the film that is unusual? I think it is the non-standard solution, which is an unexpected ending, which electrified the jurors and foreign viewers. There is a turn of events which determines the significance of the whole picture. As it turns out, it is not a film about youthful dreams of speed and freedom that are associated with a luxurious car or race, but primarily about changing perspectives, determining new priorities, deciding almost instinctively what is more important: youthful dreams or new, unknown future. But let us start with the description of the last few scenes.

When Marc is trying to get the money, he meets a young girl Michèle (Catherine Duport), and they together embark on a journey. In the end they manage to rent a car from the boy's boss. The young couple arrives in the town where the car race is to start. An old landlady leads them up the stairs to a small room. The boy and the girl are clearly amused. They are wearing wigs and are smiling. In the room with light walls there is only an old metal bed. The girl lies down on the bed and covers herself with a lacy duvet. At that time, the boy is taking a shower. He is clearly excited by what is going to happen: the night, the girl, the race. When he returns he turns on a slide projector and they watch pictures from her past. Michèle comments in a low voice on what they depict: her as a baby on a blanket, as a teenager doing gymnastics, as a model or as a beautiful young woman. After a while the girl becomes tired and falls asleep on the bed. The projector is still on. Too much illumination causes her last picture - as a teenager with two ponytails - to slowly melt, after a while we can only see a black and white spot on the screen and the end of the photographic film. The boy turns off the projector, lies down on the floor, at the

\footnotetext{
${ }^{4}$ Rysopis. Jerzy Skolimowski o sobie (Identification Marks. Jerzy Skolimowski about himself). An interview by Jerzy Uszyński, "Film na Świecie" 1990, no. 1-6, p. 23.
} 
foot of the bed. Earlier we see a few of his delicate gestures towards the girl, which suggest that he has special feelings for her. At first he passionately tells her and demonstrates to her his childish fascination with cars and speed. Then, when she is sleeping, he discreetly kisses her hands and is sneaking up to the bed. The picture fades to black ... The girl wakes up and sits up on the bed. The boy is standing by the window, from behind which we can hear the sounds of car engines whirring. The race started without him. The boy turns back, we see his serious, focused face. After a while we see him again. This time Marc makes a meaningful gesture: he covers his face with his hands, as if after removing the hands he really wanted to wake up from a dream ... It seems that he made a choice earlier, maybe in the evening. He surpassed the threshold of youthful dreams into adulthood: he stayed with a woman. He approaches the bed on which the girl is lying covered with the duvet. Is it the same person? Earlier she was a brunette (or maybe she was wearing a wig?). In the bed there lies a blonde. Or maybe it is a more general message that there is no boy with a naked woman in the room anymore, but a man? The film ends with a curious repetition of the scene with the girl's burning picture. This time it is not the photo but the film image with the boy's face looking intently at the girl that is burning. In the background, we can hear the whirring of cars pulling out. The film ends with a white, empty frame. In the evening she died as a teenager. This time he has become someone else. Is he more mature, more aware of the choices, the goals he will be striving for? That we do not know. What is certain is that he has become a completely different person.

\section{Reception of the Film}

Le Dēpart was underestimated also because two things were ignored: the accidental oversleeping for the race and ambiguity of the boy's facial expression when looking at the woman lying in the bed. These two issues are worth looking into.

Youthfulness is associated with movement, speed, and rush which often evoke purely accidental events. In 1910 one of the leading futurists Umberto Boccioni wrote: "Everything is moving, rushing, changing quickly. Never do you have before your eyes a static profile, it keeps appearing and vanishing ... Moving objects multiply, change shape, following each other in the space like vibrations ...". It seems that the final scenes from Le Dêpart are such rushing and vibrating history about dreams, the past recorded on a photograph, which, like overlapping slides, is left behind and burns down, and finally love which comes to us like a recurring wave. So we cannot escape it. Bruno Jasieński wrote about it in a poem Morze (Sea) (see Figure 2).

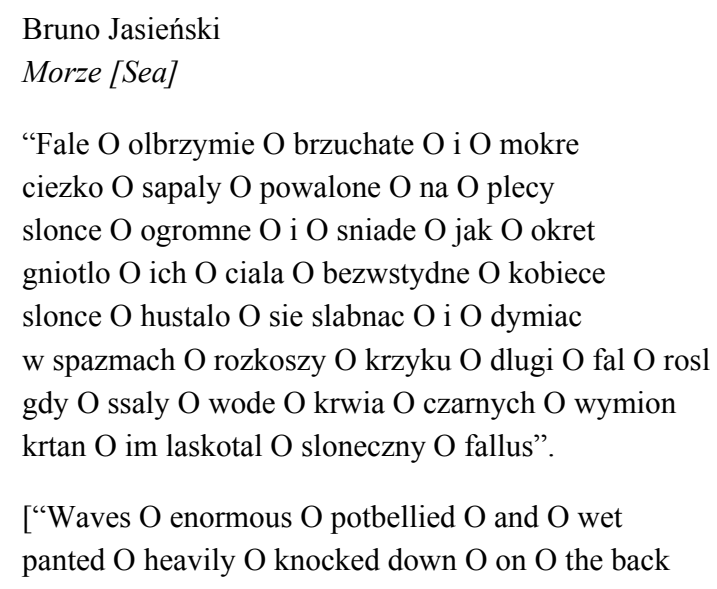




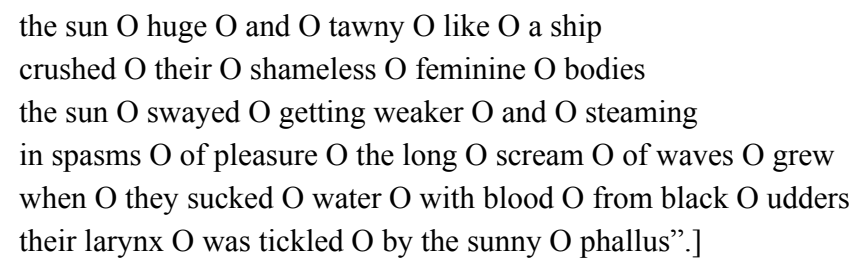

\section{MORZE}

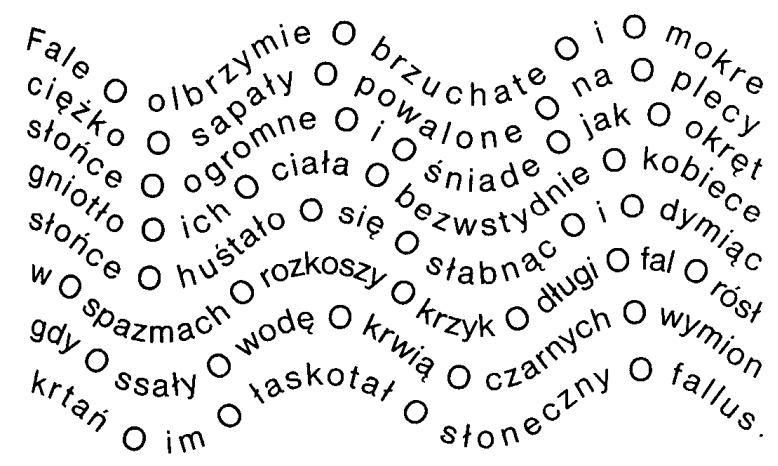

Figure 2. The poem Sea written by Bruno Jasieński (1921).

Skolimowski's vision is much more subtle, but it has some commonalities with the waviness, repetitiveness, and therefore recurrence, which the poet managed to capture both in words and in the non-standard form (visual poetry). In this case, the wavy composition of individual waves imitates the wavy shape of waves. Everything returns like a wave. The film's protagonist has to decide or choose something. The past is recorded in the pictures.

At the end there is another repetition. We can see the boy's face, a burning picture and a white screen. It is a strange face, motionless, emotionless, and serious. Focused on the place where the girl is lying. Is there tenderness in this look, which we saw in the boy's evening gestures? Rather not. The face is impassive. Or is there coldness, indifference, behind which there is anger that he did not manage to take part in the race? Supposedly, maybe even contempt. But we know how illusory what we think we are seeing can be. Sometimes a face from close range can appear calm, but from afar the expression changes. How is it possible? Visual illusion. ${ }^{5}$ Or yet another possibility: a face changes suddenly when the person concerned knows that they are no longer being watched. They are able to hide their true feelings only for a moment, to bear the gaze of the person looking, in order to invalidate everything in a second, when the looking person's eyes lose interest. Similarly, it is difficult to interpret the metaphorical meaning of the white, which remains before our eyes after the last picture gets burned. The ending is depicted as perfidiously as in the poem Nic (Nothing) by Jasienski (see Figure 3), in which there is nothing but the title. Will anyone dare to interpret such a poem, such emptiness?

\footnotetext{
5 See V. S. Ramachandran, D. Rogers-Ramachandran, Złamany kod da Vinci. Co wspólnego majq Mona Liza i Abraham Lincoln? (A broken da Vinci code. What do Mona Lisa and Abraham Lincoln have in common?), "Świat Nauki", 2008, no. 1 (9), pp. 78-81.
} 


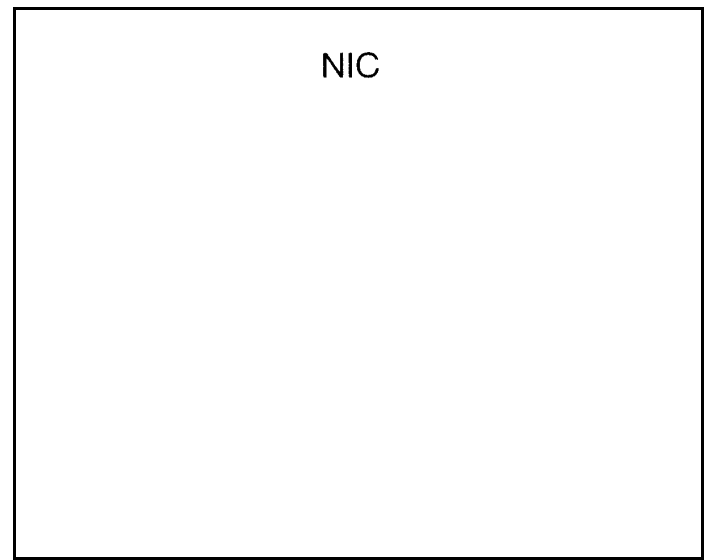

Figure 3. The poem Nothing written by Bruno Jasieński (1921).

A blank page. Is this the price of love? Supposedly love is priceless. Then it is for immaturity, and in the case of Le Dēpart, the protagonist has to pay for maturity with his dream not being fulfilled. But it was an old dream. Maybe the fact that it has not been fulfilled means that it is time to fulfill a completely new one (see Figure 4).

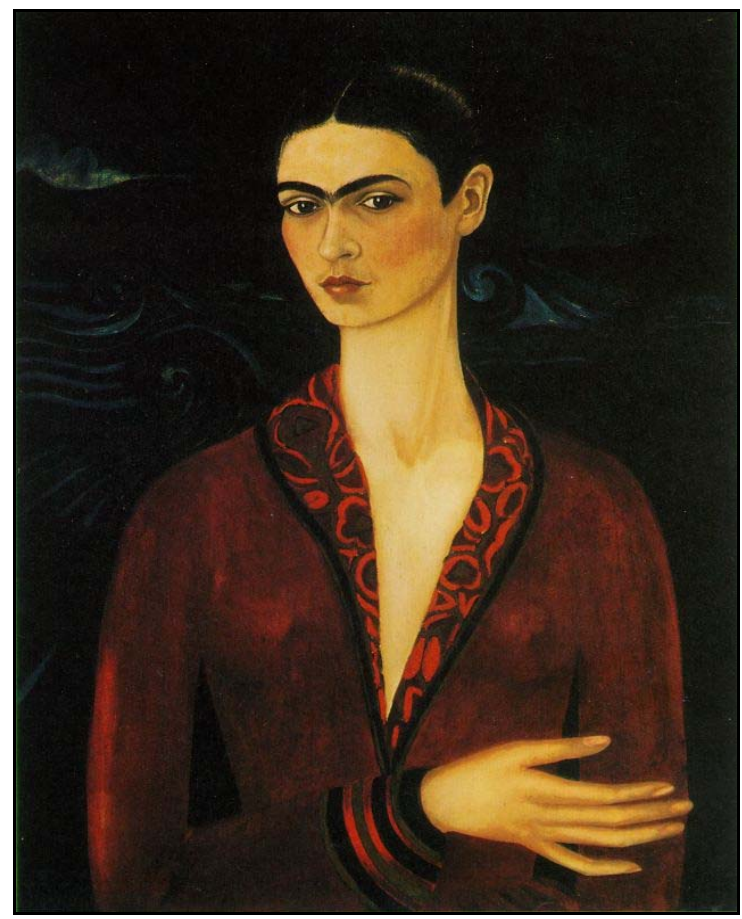

Figure 4. Frida Kahlo "Self-portrait” 1926.

\section{Conclusion}

Sometimes we watch a film after many years in order to miraculously find one unnoticed scene, which determines the significance of the whole picture. In the first foreign film by Skolimowski such a scene (or rather the whole sequence) is the ending of Le Deppart. For three reasons: the protagonists underestimated the significance of their first night together (it has changed the course of events, which were so important to them); the director "set the bar" high for the viewers (avant-garde recurrence of images, laconism of dialogues, 
completely unreal, conjured up sounds); and the viewers disregarded or gave up an attempt to interpret the boy's facial expression. I think that for these reasons only the film is worth seeing one more time ... this time in order to "open up" the mystery that was missed the first time.

\section{References}

B. S. (1967). Filmy, o których się mówi (Films that are talked about). Le Dēpart (Start). Film, 23, 3.

Filmy, o których się mówiło w 1967 roku (Films that were talked about in 1967). (1967). Film, 51-52, 14-15.

Jackiewicz, A. (1967). Skolimowski belgijski (Belgian Skolimowski). Film, 50, 14.

Nabokov, V. (n.d.). Lolita. Retrieved from http://genius.com/Vladimir-nabokov-lolita-chapter-three-annotated

Oleksiwicz, M. (1969). Podarunek dla aktora (A gift for an actor). Film, 10, 5.

Ramachandran, V. S., \& Rogers-Ramachandran, D. (2008). Złamany kod da Vinci. Co wspólnego mają Mona Liza i Abraham Lincoln? (A broken da Vinci code. What do Mona Lisa and Abraham Lincoln have in common?). Świat Nauki, 1(9), 78-81.

Skolimowski, J. (1990). Rysopis. Jerzy Skolimowski o sobie (Identification Marks. Jerzy Skolimowski about himself). (An interview by Jerzy Uszyński). Film na Świecie, 1-6, 23. 


\section{Appendix A}

Translated Iwona Mazur and Iwona Grodź

Le Dēpart

Polish title: Start

Directed by: Jerzy Skolimowski

Written by: Jerzy Skolimowski, Andrzej Kostenko

Director of photography: Willy Kurant

Music: Krzysztof Komeda

Production: Belgia

Technical data: Black and white. $2492 \mathrm{~m} .91 \mathrm{~min}$.

Awards: 1967 - Jerzy Skolimowski Berlin (IFF) - Golden Bear 